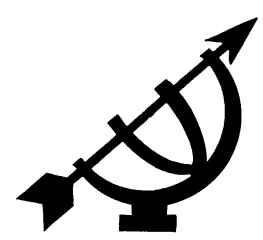

\title{
Writing "new" decalogues: Martin Luther's development of the Pauline-Augustinian tradition of natural law
}

\author{
Andries Raath \\ Department of Constitutional Law \& Philosophy of Law \\ University of the Free State \\ BLOEMFONTEIN \\ E-mail: raathA.RD@mail.uovs.ac.za
}

\begin{abstract}
Writing "new"decalogues: Martin Luther's development of the Pauline-Augustinian tradition of natural law

This essay argues in favour of Martin Luther subscribing to the theory of natural law in his theology. An in-depth study of Luther's views on natural law finds support for Brown's thesis that Luther's contribution to the tradition of natural law cannot be taken to form the basis of the theory of divine right prominent in the seventeenth century. Without venturing into the debate on natural law versus legal positivism, it is found that the perspective emanating from Luther's natural law theory has an important political message for mankind as a whole in its implicit warning against positivistic and legalistic perspectives on law because these are apt to lead to confusion, relativism and historicism. Man, according to Luther's view, therefore, has to revert to more fundamental principles (or values), representative of "ideal," "good," or "true," norms for testing manmade law. The more specific implications of Luther's views on natural law for Christians concern an eschatological vision of Christians' involvement and work in God's creation. This vision concerns man's divine appointment to hold office and promote peace in society, and to contribute humbly towards God's involvement in societies suffering from the effects of legalism or torn apart by conflict.
\end{abstract}




\section{Opsomming}

Die skryf van "nuwe" dekaloë: Martin Luther se ontwikkeling van die natuurregtradisie van Paulus en Augustinus

Hierdie artikel verdedig die standpunt dat Luther 'n natuurregbenadering in sy teologie geakkommodeer het. 'n Diepgaande studie van Luther se natuurregstandpunte word ondersteun deur Brown se opvatting dat Luther se bydrae tot die natuurregtradisie nie vertolk kan word as die grondslag vir die teorie oor die goddelike reg van konings wat gedurende die 17de eeu gegeld het nie. Sonder om betrokke te raak by die debat oor natuurreg versus juridiese positivisme, is bevind dat die boodskap van Luther se natuurregteorie belangrike politieke implikasies vir die hele mensdom inhou. Luther waarsku naamlik teen positivistiese en legalistiese beskouinge van die reg omdat dit kan lei tot verwarring, relativisme en historisme. Volgens Luther se standpunt moet die mens terugkeer na meer fundamentele beginsels (of waardes) wat verteenwoordigend is van "ideale", "goeie of "ware" norme waaraan die mensgemaakte reg getoets kan word. Meer spesifiek behels Luther se sienings oor die natuurreg 'n eskatologiese visie van die Christen se betrokkenheid by en arbeid in God se skepping. Hierdie visie is daarop gegrond dat die mens deur God aangestel is in sy amp en vrede in die samelewing moet handhaaf. Ook impliseer hierdie visie dat die mens sy gesag van God ontvang en dat hy in nederigheid moet bydra tot God se betrokkenheid by samelewings wat ly onder die gevolge van legalisme of wat deur konflik uiteengeskeur is.

\section{Introduction}

In his article "Martin Luther: a Natural Law Theorist?", Harvey Owen Brown (1987:13-25) convincingly shows that Martin Luther did espouse a theory of natural law and that his contribution to the tradition of natural law cannot be taken to form the basis of the theory of divine right prominent in the seventeenth century (Brown, 1987:22). The main argument in Brown's thesis is that a clear difference exists between the existence and the exercise of a right those who possess a right may exercise that right in whatever manner they wish (Brown, 1987:22). The theory of the divine right of kings was a basis of legitimacy for the personal powers of aristocrats, which right was bestowed by God on a particular man to rule by his own will (Brown, 1987:22).

Brown's arguments in refuting the interpretations of the divine right of kings of Luther's political and legal theory are bolstered further by an investigation into Luther's espousal and development of the 
Pauline tradition of natural law via St. Augustine's synthesis of reason and will in the concept of Christian love.

- Firstly, this view implies that neither man's reason nor his will is most fundamental in understanding and interpreting the precepts of natural law, but rather the principles of neighbourly love as embedded in Scripture. ${ }^{1}$

- Secondly, Luther's theory of natural law leaves no room for the idea of rulers governing by their own will, or for the idea of supreme power unaccountable to any other external authority. Instead of rulers attempting to impose religion in terms of practical political aims, or moralists wanting to bring to the real world truth, justice, peace, and good will, Luther's theory of natural law pleads for every person to exploit the power of the Holy Spirit, love and the Word, to inspire society to love, justice and fundamental reformation.

Not only did Luther's development of the Pauline-Augustinian concept of spiritual moral law represent a novel contribution to natural law thinking; it also represented a more practical guide for rulers to know, interpret and enforce the precepts of natural law, because, as Ebeling $(1963: 71,75)$ says, law for Luther is an "existential category" which sums up the theological interpretation of a human being as it in fact is. Law, therefore, is not an idea or an aggregate of principles, but the reality of fallen humanity.

This essay focuses on some of the ontological, epistemological and anthropological implications of Luther's unique development of the idea of the spiritual moral law of love in the Reformational tradition of natural law theory.

\section{Pauline-Augustinian perspectives on natural law in early Christianity}

\subsection{St. Paul and voluntarism in the early Christian tradition of natural law}

Luther's perspectives on natural law are solidly based upon natural law views of early Christianity, and in particular upon the idea of a

1 Some of the most important studies on Luther's natural law perspectives are contained in Troeltsch (1960), Holl (1932), Lau (1933), Wünsch (1936), Heckel (1953), Wolf (1954), Siirala (1956), Schloemann (1961). 
supernatural law superceding positive law. Arguably the strongest emphasis in the legal theory of early Christianity was on supernatural law. In his letters St. Paul referred to the "law written in men's hearts"2, and accepted the fact that the Gentiles who do not have God's Law revealed in Scripture, do by nature the things as required in the law. ${ }^{3}$ Although there are indications in Paul's letters that he took the divine will to be accessible to human reason, he denied the traditional aid to reason in this task. To Paul, the Greek aid, human nature, is, instead, a sinful stumbling block to be overcome. The overall impression of St. Paul's views is that God's dictates are not to be understood in terms of human understanding and are not rational in terms of human thinking. To Paul the obviously necessary knowledge of the divine will can only be spiritually discerned4, and this only in the sense that God has made it known to us "according to his good pleasure which he hath purported in himself". 5

Paul can be described as the apostle of the will of God, which "has no other ground to will as He wills than that He wills so" and not in any other way. 6 With only minor exceptions Paul subscribed to the predominant natural law thinking of his time. However, his emphasis

$2 \quad$ E.g. Rom. 2:14, 15.

3 Romans 2:14-15. What Paul says here in effect means that there is no light of nature that is not kindled by the grace of God. When Gentiles, who do not have the law, do, by the influence of God upon their hearts, the things contained in the law, they are a law unto themselves; that light and influence serving instead of a divine revelation - no natural light is kindled there but by the grace of God.

4 Corinthians 2:11,14.

5 Ephesians 1:9; cf. Romans 5:5. Because the love of God is shed abroad in our hearts we have the most solid and convincing testimony of God's love to us, by that measure of it which He has communicated to our hearts. It is poured out: filling, quickening, and invigorating all our powers and faculties. This love is the spring of all our actions; it is the motive of our obedience; the principle through which we love God - we love Him because He first loved us; and we love Him with a love worthy of Himself, because it springs from Him. The Holy Spirit comes with it. Therefore, we are furnished with every good word and work; have produced in us the mind that was in Christ; are enabled to obey the pure law of God in its spiritual sense, by loving Him with all our heart, soul and mind, and strength; and our neighbour, any and every soul of man, as ourselves.

6 In Romans 1:1, St. Paul's allusion to himself as a servant of God's will, suggests by implication that he is a slave; one who is entirely the property of his Master; one who is in the strictest subservience to the will of his Lord; one who is wholly devoted in the spirit and sacrificial obedience to the constant, complete and energetic performance of the divine will. 
on God's will as the source of ethical norms assisted in introducing voluntarism into the Christian views on natural law prevalent in early Christianity.

\subsection{St. Augustine and the synthesis of reason and will in the principle of love}

The philosophical and political conceptions of early Christians were substantially the same as those in the Stoic tradition - Christians, similar to the Stoics, believed in the law of nature, the providential government of the world, the obligation of law and government to do substantial justice, and the equality of men in the eyes of God. The Fathers of the early church, particularly St. Augustine, revised and reinterpreted these concepts and ideas in the light of the natural law theory of pagan antiquity and St. Paul's views on man's reason, God's image in man and the working of the Holy Spirit to engender and kindle love in the hearts of fallen mankind. Augustine developed a perspective on natural law which carried forward Paul's teaching of natural law into the Reformed tradition, the essence of which constituted the platform for Luther's Reformational position on natural law.

\section{- God speaks to everyone through the lex naturalis}

To St. Augustine, the fundamental precepts of the natural law or lex naturalis are known, or can be known, by all men of right reasoning, no matter how morally depraved these men may be. God, who inscribed the eternal law (lex aeterna) on the hearts or souls or minds of all men, speaks to everyone through the lex naturalis. Therefore no one, not even heathens, unbelievers, or the most depraved people may plead ignorance of the lex naturalis. According to St. Augustine even heathens, unbelievers and morally depraved men may have devised a number of most useful precepts. Natural justice, to St. Augustine, firstly consists of rendering unto everyone his due - the suum cuique tribuere - and natural justice must always be related to the common (or universal) good or common utility. St. Augustine explains the nature of the suum as the maintenance of the most perfect order, a situation in which everything and everyone has a role to play in accordance with the position held in this universal order.

\section{- The law as both love to God and to our neighbour}

The second principle of St. Augustine's natural law theory expresses the idea that in addition to the first rule, one should "do nothing unto another that you would not have done unto yourself". This view 
constitutes the content of the lex naturalis. The two moral precepts, namely, to "render unto everyone his due" and "to do nothing unto another that you would not have done unto yourself", constitute the primary principles of natural law (On Christian Doctrine, 13, 14, 22). ${ }^{7}$ Every other precept of natural law, in the final analysis, is but a conclusion from, or application of, these two basic guidelines. To Augustine the basic principles of natural law operate in the public interest. He argues that because God's eternal law is engraved on the human soul in the form of the principle to give to everyone his due and therefore the furtherance of the public interest, the common interest should ultimately be reflective of Christian love. Furthermore nobody can act justly without love.

\section{- Natural law reflects the will of God}

Because natural law reflects the will of God, it "mediates", so to speak, between God's eternal law and man-made law in maintaining universal peace - natural law being a manifestation of God's eternal law. The laws of man's nature move him to hold fellowship and maintain peace in their own circle. The law of nature's primary aim is to maintain universal peace, by which every one receives his desert.

Natural law constitutes a universal order of love which is inculcated by God's Spirit, for without the gift of God, that is, without the Holy Spirit, through whom love is "shed abroad in our hearts, the law can command, but it cannot assist; and, moreover, it makes a man a transgressor, for he can no longer excuse himself on the plea of ignorance" (Encheridion, 18:540). ${ }^{8}$ Love is the culmination of all the commandments because God Himself is love. All God's commandments are rightly carried out only when the motive principle of action is the love of God, and the love of the neighbour in God (Encheridion, 118:542 ff.). Augustine now applies the distinction between the two covenants to the writing of the law on tablets of stone in the Old Testament, and the new law written on the flesh of the heart. In the Old Covenant the Law is an external

7 All references to this source reflect the book, chapter and paragraph. Augustine addresses the error of those who think that there is no absolute right and wrong. He takes the precept "whatsoever ye would that men should do to you, do ye even so to them" to be unalterable by the diversity of national customs: "And this precept, when it is referred to the love of God, destroys all vices when to the love of one's neighbour, puts an end to all crimes. For no one is willing to defile his own dwelling ... And no one wishes an injury to be done him by another; he himself, therefore, ought not to do injury to another." 
thing written on stones; in the New, it is written internally on the heart, so that men now wish to do what the law prescribes (AntiPelagian Writings, 35). 9 The writing on the heart is nothing other, Augustine explains, than the shedding abroad by the Holy Spirit of love in our hearts, so that we love God's will, and therefore freely do it. The Holy Ghost is called the "Finger of God" because the tables of the law were written by the Holy Spirit, by whom we are sanctified in order that, living by faith, we may do good works through love (Anti-Pelagian Writings, 35). 10

Obedience to the precepts of natural law is only possible through the graceful working of the Spirit restoring the love demanded by God's will (Anti-Pelagian Writings, 103). Therefore, says Augustine, the law, by teaching and commanding what cannot be fulfilled without grace, demonstrates to man his weakness in order that the weakness, thus proved, may resort to the Saviour, by whose healing the will may be able to do what it found impossible in its weakness. So, then, the law brings us to faith, faith obtains the Spirit in fuller measure, the Spirit sheds love abroad in us, and love fulfils the law (Anti-Pelagian Writings, 42). There is no fulfilment of the law except through love; and of course the love of God is shed abroad in our hearts not by ourselves, nor by the force of our own will, but by the Holy Spirit who is given to us (Anti-Pelagian Writings, 42).

In the context of Augustine's theory of natural law it is important to note that he does not reject or "demonise" man's faculties of reason and will outright as manifestations of sin. Man's reason and will are both elements of rationality (see On Christian Doctrine, 10, 3 (39811)). Through the Fall into sin, man's rational and voluntary functions have become deformed and contaminated. As a result thereof both man's ability to know what is right and to act correctly have become blurred and dimmed through sin. Through the working of the Word and the Spirit man's knowledge of natural law and justice is restored; Christians should therefore have a clearer and

9 References to Augustine's Anti-Pelagian Writings only indicate the page references.

10 In his Anti-Pelagian Writings, 65, Augustine holds that the law of the Spirit of life is nothing other than the same law written in the heart (Jer. 30:1, 33). At 278 Augustine states that the teaching of the law without the life-giving Spirit is the "letter that killeth". At 297 he affirms the view that the letter of the law teaches us not to commit sin, or kill, if the life-giving Spirit is absent.

11 Book 10, Chapter 3 (page 398). 
more profound knowledge of the basic tenets of natural law. The Word and the Spirit enable believers to know, understand and interpret natural law in spite of the impact of sin on man's basic knowledge of and insight into the tenets of natural law (Treatise on Spirit and Letter, 30:319).

\subsection{Martin Luther and the Pauline-Augustinian tradition of natural law}

In his social and political thought Luther, partially under the influence of Augustine's doctrine of the two kingdoms in conflict, teaches that the Kingdom of God will ultimately prevail (see Nichols, 2002:133). Contrary to Augustine, Luther subscribed to the value of the earthly kingdom, that the Christian is a citizen of both kingdoms, subject to their laws and customs and participant in the activities of each, and that God's law concerns both kingdoms - the first great commandment, to love God with one's whole heart, soul, mind and strength, concerns the Kingdom of God, whilst the second, to love one's neighbour, governs Christians' life in the earthly kingdom. 12 God did not leave mankind without clear indications on how to be good citizens of both kingdoms. The summation of the law as both love to God and to our neighbour, governs man's relationship with God and with his neighbour respectively (Nichols, 2002:134).

Luther also borrowed from Augustine the views on Christian relationships with God, the Creator. Luther describes man's relationships in the kingdom of creation in terms of three estates reflecting God's order in the world. In his work On Temporal Authority: To What Extent It Should Be Obeyed (1523), Luther, in addition to the estates of priest, marriage and civil government, added the common order of Christian love,

... in which one serves not only the three orders, but also serves every needy person in general with all kinds of benevolent deeds, such as feeding the hungry, giving drink to the thirsty, forgiving enemies, praying for all men on earth, suffering all kinds of evil on earth, etc. Behold, all of these are called good and holy works (Nichols, 2002:235-236).

12 Luke 10:27. Luther's views on the doctrine of the two kingdoms differ only in certain minor respects from those of Augustine, so for example Luther refers to Augustine's city of humanity as the kingdom of creation, and to Augustine's city of God as the kingdom of redemption (Nichols, 2002:134). The two kingdoms, those of creation and redemption, function separately, although the Christian is a citizen of both. 


\section{Martin Luther and the spiritual law of love}

\subsection{Reason and man's fall into sin}

Luther maintains the pre-lapsarian integrity of man's faculties: the image of God, according to which Adam was created, was something far more distinguished and excellent than that after man's fall into sin, "since no leprosy of sin adhered either to his reason or to his will". Both man's inner and outer sensations were of the purest kind. "His intellect was the clearest, his memory was the best, and his will the most straightforward" (LW, 1:26 (LG); Gen. 1:27).13 God did not create man evil, He created him perfect: rational, holy, with a knowledge of God, with sound reason, and with good will toward God (LW, 2:122 (LG); Gen. 8). However, after man's fall from righteousness into sin, it is correct and truthful to say that our natural endowments are not perfect but are corrupted by sin. "For just as it is the nature of the eye to see, so it was the nature of reason and will in Adam to know God, and to fear God" (LW, 1:165 (LG); Gen. $3)$. Just as leprosy poisons the flesh, so the will and reason have become depraved through sin, and man not only does not love God any longer but flees from $\mathrm{Him}$, hates $\mathrm{Him}$, and desires to be and to live without Him; the will is impaired, the intellect depraved, and the reason entirely corrupt and altogether changed (LW, 1:165 (LG); Gen. 3).

13 Unless otherwise indicated, references to $L W$ are to Luther's Works (Luther, 1958-1967). The specific work of Luther referred to, is noted, e.g. Lectures on Genesis (LG), and the relevant scriptural citation given where applicable. Abbreviations for Luther's particular works used: Lectures on Genesis (LG); Selected Psalms (SP); Lectures on Galatians (LGS); Sermon on the Mount and the Magnificat (SM\&M); Sermons on the Gospel of St. John (SJ); The Confession Concerning Christ's Supper (CCS); An Exhortation to the Knights of the Teutonic Order (ETO); Sermons (S); Table Talk (TT); Lectures on the Minor Prophets (LMP); Treatise on Good Works (TGW); The Catholic Epistles (CE); Lectures on Titus, Philemon and Hebrews (TP\&H); Admonition to Peace. A Reply to the Twelve Articles of the Peasants of Swabia (AP); Whether Soldiers, too, Can be Saved (SS); The Bondage of the Will (BW); Word and Sacrament (W\&S); A Sermon on Keeping Children in School (KCS); On the Councils of the Church (CC); Personal Prayer Book (PB); An Exposition of the Lord's Prayer (LP); Trade and Usury (TU); On Marriage Matters (OM); Disputation Concerning Justification (DJ); Temporal Authority. To What Extent It Should Be Obeyed (TO); Prefaces to the Books of the Bible (PB); Theses Concerning Faith and Law (F\&L); Appeal Against the Heavenly Prophets (HP); Commentary on Romans (CR). References to WA are to the standard edition of Luther's Werke (Kritische Gesamtaugabe - Weimar, 1883), and to MA are to his Ausgewählte Werke (or Münchener Ausgabe). 
Luther vehemently opposes the scholastic principle of the inherent goodness of man's reason: after the Fall man's reason is the "blind fool" (LW, 21:260 (SM \& M); Matt. 7), "insane" (LW, 21:260 (SM \& M); Matt. 7); reason is "ignorant" (LW, 22:459 (SJ); John 14: 15); it is the bride of the devil - "Dame Witch" (LW, 22:459 (SJ); John 14:15); the "old witch, lady reason" (LW, 37:210 (CCS)); the "devil's whore" (LW, 45:145 (ETO)); it is a "mangy, leprous whore" (LW, 51:375 (S); Rom. 12; Sermon in Wittenberg on January 17, 1546); a "cursed whore" (LW, 51:78 (S); John 1; Gospel for the Main Christmas Service); the "old man, the enemy of God (LW, 52:79 (S); John 1; Gospel for the Main Christmas Service); "Proud reason" (LW, 52:149 (S); Luk. 2; (Gospel for the New Year's Day); "arrogant reason" (LW, 52:149 (S); Luk. 2; Gospel for New Year's Day); "Frau Hulda" (LW, 37:318 (CCS)), and other similar terminology. ${ }^{14}$

The fact that man's reason has fallen into sin does not extinguish the possibility of it being regenerated through faith and the Spirit of God. Although reason under the devil's control is harmful, for example in the case of the learned men who on the basis of their reason disagree with the Word, when the Holy Spirit illuminates it, on the other hand, reason helps to interpret the Holy Scriptures. Although it is the same "instrument" in both instances, whether before or after faith, reason, when illuminated by the Spirit, helps faith by reflecting on something, but reason without faith is not and cannot be helpful. Reason that is illuminated takes all its thoughts from the Word. "The substance remains and the unreal disappears when reason is illuminated by the Spirit" (LW, 54:71 (TT); No. 439, early 1533). Prior to faith and knowledge of God, reason is darkness, yet in believers it is an excellent instrument. Just as all gifts and instruments of nature are evil in godless men, so they are good in believers. Reason, speech and eloquence now further faith, whereas these were only impediments prior to faith. Enlightened reason, taken captive by faith, receives life from faith, for it is slain and given life again. As our body will rise glorified, so our reason is different in believers than it was before. Reason, speech and all gifts and created things are therefore different in believers and Christians than in unbelievers (LW, 54:182 (TT); No. 2938b, between January $26 \& 29,1533)$.

14 E.g. in his Admonition Concerning the Sacrament of the Body and Blood of Our Lord (LW, 38:128 (SBB)), Luther calls reason the "Devil's Mother". 


\subsection{Reason, the Word and the Holy Spirit}

Luther recognises a close relationship between the work of the gospel and the enlightening work of the Spirit.15 Commenting upon John 1:5, Luther criticises Augustine's Platonic interpretation of man's reason being illuminated through the light of the Gospel:

For natural life is quickened by the divine life in exactly the same manner as the light of reason is illuminated by the divine light. Hence, in all fairness, they should also say that life quickens the dead, and the dead do not comprehend it. Again, I might also say: The eternal will makes the unwilling willing, and the unwilling do not comprehend it. We could deal in the same manner with all our natural gifts and powers. How is it that reason and its light enter into such speculation? Platonic philosophers first led St. Augustine to this interpretation with their unprofitable and silly babbling. Their interpretation glistens so nicely that they were called the divine philosophers. Augustine in turn pulled us after him

$$
\text { (LW, 52:57 (S)). }
$$

This light is a gift of grace, which is given to men in addition to the natural light, and it shines in the darkness, i.e., among the blind people of this world who are without grace, yet they do not accept it. On the contrary, they persecute it (LW, 52:57 (S)). Through the gospel this light is brought to us; it is very near to us and also shines in our hearts. Nothing is more necessary than that it be pointed out and preached. And whoever hears it preached, and believes, finds it in his heart; for faith can only be in the heart, and so this light cannot be anywhere except in faith. Because this light is within us, although it is not comprehended by us on our own, it must be preached and believed. "This is what St. Paul has in mind in Romans 10[:6-8] where he refers to Moses' statement in Deuteronomy 30[:12, 14]:

'It is not necessary to travel across the ocean, nor to climb into heaven or into hell for it. It is near to you, in your heart and in your mouth.' See, this is what was meant by the light shining in darkness and not being comprehended until John and the gospel came and revealed it. Then man is illumined by it and

15 Because the work of the Holy Spirit is described by Luther as the work of faith faith receives the Spirit and is at the same time at work. Therefore, faith and the Spirit are one. See $L W, 35: 70-71$ (PB): "Faith is a living, daring confidence in God's grace, so sure and certain that the believer would stake his life on it a thousand times. This knowledge of God and confidence in God's grace make men glad and happy in dealing with God and with all creatures. And this is the work which the Holy Spirit performs in faith." 
comprehends it, and yet it changes neither time, place, person, nor age, but only the heart

(LW, 52:57 (G); The Gospel for the Main Christmas Service, John 1: 1-14).

Reason enlightened by the gospel will draw man's sinful will in its wake. Luther argues as follows: there are three parts to man, namely reason, desire, and dislike. All man's works are done under the impulse of these (LW, 44:78 (TGW)). If the "light", reason, "the old deceit", is now dead, dark, changed into a new light, then man's entire life and all of his powers must follow after the new light and be changed. For wherever reason goes, there the will follows. Wherever the will goes, there love and desire follow. Man in his totality must crawl into the gospel and become new. "He must shed his old skin as does the snake" (LW, 52:78 (S); The Gospel for the Main Christmas Service, John 1:1-14).

Contrary to the perfect will of God, man's will is sinful and fallible, therefore, "(o)ur will is unimportant; God's will and choosing are decisive" (LW, 30:6 (CE); 1 Pet. 1). Although for man it is impossible to understand the will or the Law of God, one must yet try in one way or another. In the first place, God's will is expressed in every command that He Himself alone should be loved and preferred above all things. When He has begun to bring this about and to fulfil this will, He strips and divests man inside and outside of every work of his (LW, 29:185 (TP \& H); Heb. 6). It is God's will that in the temporal domain kings be honoured and rebels destroyed (LW, 46:18 (AP)). We must serve, obey and do our duty to our prince, according to God's will (LW, 46:132 (SS)). The almighty God bestows great grace upon us when He appoints rulers for us as an outward sign of His will, so that we are sure that we live in accordance with His divine will and act correctly, whenever we act in line with the will and pleasure of the ruler. God has attached and bound the ruler's will to us when He says, "Render therefore to Caesar the things that are Caesar's" 16 and, "Let every person be subject to the governing authorities". 17 The whole world, according to Luther, ought to think of this as a great joy and comfort and even as a compelling reason to love and honour those who rule over us (LW, 46:134 (SS)). 


\section{Luther on natural law, reason and God's will}

\subsection{Luther and the early interest in natural law}

Partly because of the new attention being devoted to classical antiquity, Luther's contemporaries in several academic fields, particularly law, philosophy and theology, have paid considerable attention to the relationship between natural law and the positive or written law of nations. Luther himself often discussed this relationship, as well as the connection of both natural and positive law with the Law as contained in the Scriptures, especially the Ten Commandments. 18 In his commentary on Psalm 101:2, Luther responds to the prevailing interest in natural law thinking by stating that "(a)t present people are beginning to praise natural reason as the source from which all written law has come and issued". Luther objects to the new interest in terms of which natural law is equated with natural reason, stating that the trouble is that everybody likes to think that natural law is "encased in his head". He continues:

If natural law and reason were inherent in all heads, then fools and children and women would be just as capable of ruling and waging war as David, Augustus, and Hannibal ... therefore it is also a fact that among those who presume to have natural reason or natural law and boast of it, there are many great and efficient natural fools. The noble gem called natural law and reason is a rare thing among the children of men

$$
\text { (LW, 13:160; (SP); Ps. 101). }
$$

Luther states that certain people are gifted to know the precepts of natural law more clearly and better than others. There are, according to Luther, certain extraordinary leaders, into whose hearts and minds God puts it, that they may earnestly undertake it and also carry it out. Such earnestness and such deeds, to Luther, are not inherent in reason or in natural law. If kings and princes follow nature and the highest wisdom, they must all become God's enemies and persecute His Word. Worldly kings, princes, and lords are enemies of God and persecute His Word. This is the natural thing for them; they are born that way. It is a natural and innate characteristic of reason (LW, 13:165 (SP); Ps. 101).

18 For Luther's use of the terms "law of nature", "natural law", "Godly law", see Beyer (1935); Heckel (1953); Cargill Thompson (1984); Tonkin (1971); Binder (1965); McNeill (1941). 
Law, to Luther, has a threefold manifestation: natural law, written law and the law of the Gospel (LW, 27:354 (LGS); Gal. 5).19 These laws all come together and are incorporated in one principle, that is love, because love is the end of every law. 20 In essence this means that where Scripture states that laws are written in the minds and hearts, it must be understood to mean that it refers to the love man should have for the law (LW, 29:197 (TP \& H); Heb. 8). This view entails that Hebrews 10:19 must be understood to mean that in the innermost affection of my heart I must love God's Law most perfectly (LW, 29:221 (TP \& H); Heb. 10).

\subsection{The essence and features of natural law}

On occasion Luther describes natural law as essentially a "spiritual law" in a "moral sense" (LW, 25:180 ff. (CR); Rom. 15). This means that natural law was inscribed in the hearts of men by the Spirit of God and that written moral law as contained in the Ten Commandments is the corollary of this spiritual law written in man's innermost being by the Spirit of God.21 As such, natural law is a

19 Although, according to popular opinion, a distinction is made between natural law, the written law, and the law of the Gospel, Luther comments on the statement of Christ to the effect that natural law is equated with the Law and the prophets: "Since He Himself, however, teaches the Gospel, it is clear that these three laws differ not so much in the function as in the interpretation of those who falsely understood them. Consequently, this written law, 'You shall love your neighbour as yourself', says exactly what the natural law says, namely, 'Whatever you wish that men would do to you [this of course, is to love oneself], do so to them [as is clear, this certainly means to love others as oneself].' But what else does the entire Gospel teach? Therefore there is one law which runs through all ages, is known to all men, is written in the hearts of all people, and leaves no one from beginning to end with an excuse, although for the Jews ceremonies were added and the other nations had their own laws, which were not binding upon the whole world, but only this one, which the Holy Spirit dictates unceasingly in the hearts of all."

201 Timothy 1:5. Luther sometimes distinguishes between the law of nature, works and faith (LW, 33:111 (BW)); natural law, written law and the law of the gospel (LW, 27:354 (LGS); Gal. 5); temporal law, the law of faith and the law of love (LW, 35:236 f. (W \& S)); and elsewhere divine law, natural law and positive law (LW, 50:29 (L 245, to Robert Barnes, Wittenberg, September 3, 1531)). Christ, too, says Luther, expressly equates natural law with the Law and the prophets (LW, 27:254 (LGS); Gal. 5).

21 Edward A. Dowey $(1984: 148)$ succinctly observes that in essence to Luther natural law refers to God's ordering of the universe and the functioning of the human will in accordance with God's will. The latter is the natural right, or justice, understood in human society as distributive justice, entailing appropriate guilt and punishment for violation. The human conscience, says Dowey, is natural right within the human soul, the ability to distinguish between right and 
creational law, instilled in man as a result of God's creational activities. In his commentary on Psalm 112:1, Luther exclaims:

God's righteousness endures forever. These divine stations and orders have been established by God that in the world there may be a stable, orderly, and peaceful life and that justice may be preserved. The Psalmist calls it 'God's righteousness'; lawyers call it 'natural law'. God had instituted these stations according to natural law

$$
\text { (LW, 13: } 369 \text { (LP); Ps. 112). }
$$

Luther asks: "What would happen if men were to set up these stations and natural law?" (LW, 13:369 (LP); Ps. 112). Being a creational law, natural law transcends men's manipulation of its precepts and content.

The general features of natural law are contained in the typical structure thereof, that is that these precepts are rationally discernable, that they postulate an ideal set of norms for making positive law, that they are presumed to be of universal applicability, that the principles underlying natural law are immutable although the application of natural precepts may be variable depending on the circumstances prevailing, and finally that the precepts of natural law are supported by divine sanction. The first feature of natural law is that it is rationally discernable - all laws, to Luther, have their origin in reason for God has subjected temporal rule and all physical life to man's reason (LW, 46:241 ff. (KCS)). ${ }^{22}$ With reference to Romans $1: 19$, Luther states that even Gentiles have a rational knowledge of the precepts of natural law - thereby knowing that murder, adultery, theft, usury, lying, deceit, and blaspheming are wrong. Their natural reason also teaches them that there is a God and that He punishes such vices (LW, 22:150 ff. (SJ); John 1). Transgressors of the law, whoremongers, murderers, thieves, "and similar rascals" therefore have to admit their wrongdoing in court, for their own conscience tells them that it is not right for one man to kill another. They have the content of the Law of God and the Ten Commandments written

wrong. Conscience to Luther, because of the revelatory character of natural law, becomes the equivalent to God-consciousness. Divine law and moral law, then, refer generally to special revelation of the universal ordering will of God for creation, particularly as republished for the chosen people in the Decalogue, and commented upon by Jews, prophets and apostles.

22 Luther relies on Genesis 2:15 for this view. See LW, 45:129 (TO); 46:242 (KCS)); WA, 11:280; 17 II:91; 30 II:562. Natural law is, therefore, accessible with reason to the extent that the Spirit enlightens reason. 
in their hearts by nature. They can recognise wrong both in themselves and in others. They, too, break the law if they do so in secret (LW, 22:150 ff. (SJ); John 1).23

\section{- Man's reason imparts knowledge about temporal life}

Essentially the knowledge imparted by man's reason pertains to the temporal order of creation, which knowledge also manifests itself in the thoughts and works of pagan philosophers. Commenting on John 14:7, Luther states that these philosophers develop all kinds of good principles from their reason, and rulers prescribe many kinds of laws and statutes that pertain to this life, in other words to man's civic life in this world, such as we lead before the world outwardly: a decent, virtuous, and moral course and conduct whereby we uphold temporal government, maintain peace, honour, and order, and promote the acquisition of goods and honour. All these means are confined to this temporal life. Therefore we dare not listen to the dictates of reason or of the law or of the notions of man, nor dare we follow them as they would show us the way in the spiritual domain (LW, 24:37 f. (SJ); John 14). However, because natural law is implanted in man's innermost being, it entails that as far as man's life in the civil sphere is concerned, natural law does give guidance to man concerning his conduct towards others. Because God implants natural law, this also entails that natural law is valid per se because man is naturally born with knowledge of what he is to do and is not to do. Luther calls this natural justice, natural law, or law of nature (LW, 40:97-98 (HP)).24

\section{- Natural law has normative content}

Secondly, natural law has normative content and serves as the standard for making positive law. 25 Laws are not things that are

23 Luther quotes Romans 2:3, $20 \mathrm{ff}$.

24 Also note WA, 17 II:102; 18:80-81; 39 I:540. Although Heinrich Bornkamm endeavours to establish a distinction between Luther's use of the terms "law of nature" (Naturrecht and natürliches Recht) and "natural law" (naturliches Gesetz) in his work Luther and the Old Testament (Bornkamm, 1969:31) Paul Althaus in his work The Ethics of Martin Luther (1972:25 n 2) does not find sufficient evidence for such a distinction.

25 Positive law (or statutory law) refers to the civil statutes of a political order, which aim to approximate the justice of natural law according to local and temporal circumstances (Dowey, 1984:184). Positive law also includes many laws in the "Books of Moses" that are merely of local significance, e.g. the civil and judicial laws, as well as the ceremonial laws. 
about to happen of their own accord. An apple bears fruit without our telling it to. From a theological perspective natural law is not what happens but what ought to happen, while some lawyers presumably of positivistic and legalistic persuasion - apply the term to what ought to happen or what is demanded. Natural law, therefore, has an authoritative validity and takes precedence over positive law (WA (TR) 2; No. 2151). Natural law determines all positive statutes - or at least it ought to determine them. Furthermore positive laws should be critically evaluated on the basis of natural law (LW, 24:228 (SJ); John 15). ${ }^{26}$ In his Table Talk, Luther describes the difference and the relationship between natural and positive law as follows:

Natural law is a practical first principle in the sphere of morality, it forbids evil and commands good. Positive law is a decision that takes circumstances into account and conforms with natural law on credible grounds. The basis of natural law is God, who has created this light, but the basis of positive law is civil authority. When theft is punished by hanging, this occurs according to positive law on acceptable grounds, not as in the case of the Draconian law $\mathbf{2 7}$ which condemned every thief to hang, even if he stole only a chicken; this has no acceptable grounds and is contrary to nature. Consequently it was said that this law was written in blood. Yet the punishment must be applied more severely among more unbridled peoples

(LW, 54:293 (TT), No. 3911: Difference

Between Natural and Positive Law, July 7, 1538).

\section{- Natural law is an imprint of moral law}

Thirdly, because natural law is an imprint of moral law in the innermost recesses of man's existence, the principles thereof are immutable, although the application of natural law precepts may differ from time to time and place to place because a person does not recognise God's will for himself independently, but only by hearing the message of Scripture. 28 However, he is not bound

26 Also see LW, 54:293 ((TT), No. 3911: Difference between natural and positive law, July 7,1538$) ;$ WA, 45:669.

27 The coded law was said to have been framed by the Athenian Draco about 621 B.C. in which every crime was punishable by death.

28 This view implies that natural laws are always and universally valid, unlike positive regulations and rules whose validity is limited to a particular time and place, they "prevail and remain in all lands" (LW, 40:97-98 (HP); LW, 46:291 
legalistically to a heteronomous word of Scripture, but, as he is moved by the Word of Christ's Spirit, he lives in "theonomous creativity" (Althaus, 1972:32). Christians who are in fellowship with Christ and filled with his Spirit are also able to establish norms and arrive at right judgements in every case that may arise (WA, 39 I:47; LW, 34:112 (F \& L); Paragraphs 51, 52: September 11, 1535).

Luther continues by observing that the dynamics of faith and the Spirit enable man to make "new" decalogues: For if we have Christ, we can easily establish laws and we shall judge all things rightly. Indeed, we would make new decalogues, as Paul does in all his epistles, and Peter, but above all Christ in the gospel. These decalogues are clearer than the decalogues of Moses, just as the countenance of Christ is brighter than the countenance of Moses, for if the Gentiles in their corrupt nature were able to know God and be a law to themselves (Rom. 2:14), how much more is Paul or the perfect Christian, full of the Spirit, able to set in order a certain decalogue and judge more correctly about all things, just as all the prophets and patriarchs spoke all things which are contained in the Scriptures by the Spirit of Christ (LW, 34:112 (F \& L); Paragraphs 52-57: September 11, 1535). Man's creative deepening of the "new" decalogues" expresses the intention of God's commandments "more completely and more deeply than the Mosaic decalogue does" (see Althaus, 1972:31). Christians are thus called to make creative decisions and to use their own conscience to decide what God commands here and now (LW, 45:245 (T \& U)).

Althaus interprets Luther's position to mean that Christians cannot arrive at the necessary decision simply by reading the directions given in the Bible or by finding applicable statements in the New Testament - such directives have to be applied under the guidance of the Spirit in order to promote justice more fully (Althaus, 1972:31). The directives in the Bible, to Luther, are not adequate in terms of specific situations that are different from previous situations. The duty of Christians to abide by Biblical directives does not free us of the continual need to interpret these precepts in new ways. Because the Spirit is given in varying degrees not all Christians are called to the same measure of creativity in interpreting the Word. Christianity is called upon to undertake this duty through its teachers (WA, 39 I:47; LW, 34:113 (F \& L)). At every moment of his life a Christian is subject to the precepts of natural law and he is called upon to

(OM); LW, 14:14 (SP); WA, 30 III:225; 31 I:233). Positive laws must be changed as circumstances require; natural law, however, is unchangeable. 
interpret these precepts freely in terms of the nature of Christian love - he has to "update" them on the basis of the whole gospel in order to apply them to contemporary problems in a "new way", similar to interpreting the Mosaic decalogue and the New Testament directives as "new decalogues" (Althaus, 1972:32). By virtue of his fellowship with God, a Christian is called to freedom of conscience even in his fellowship of God's commandments. In his fellowship he is justified and certain that God is well pleased with him (WA, $6: 207) .29$

\section{- Natural law is supported by divine sanction}

Fourthly, natural law is an authoritative system of law because it is supported by divine sanction. Natural law, based on divine sanction, fulfils a most important function in maintaining the order demanded by God. In this life we need government and parents, who uphold discipline by means of rewards and punishments, and who keep the Law and govern and direct their conduct in a godly and prudent manner according to the norm of the Law (LW, 8:170 (LG); Gen. 48:19).

Luther's reliance on St. Paul's observations about natural law in Romans 2:15 enables us to formulate a condensed version of his definition of natural law that could read as follows: natural law is a common judgment to which all men alike assent and therefore one which God has inscribed upon the soul of everyone. $\mathbf{3 0}$

29 Luther states: "Thus a Christian man who lives in this confidence toward God knows all things, can do all things, ventures everything that needs to be done, and does everything gladly and willingly" (LW, 4427 (TGW)).

30 Note the definition by Luther's follower, Melanchthon in The Loci Communes of Philip Melanchthon (Melanchthon, 1944:122). Also note LW, 40:97-98 (HP). Luther frequently cited Matthew 7:12 and Luke 6:31 when speaking of the natural law of love. Also see Karl Holl (1932:265 n 1). Although Luther himself does not provide a definition of natural law, in LW, 26:53 ((LG); Gal. 5:14) he mentions some of the features of natural law: "All men have a certain natural knowledge implanted in their minds (Rom. 2:14-15), by which they know naturally that one should do to others what he wants done to himself (Matt. $7: 12$ ). This principle and others like it, which we call the law of nature, are the foundations of human law and all good works." For Luther the Decalogue summarised and sharpened natural law for special purposes in the history of salvation, chiefly to accuse the consciences of those who thought themselves righteous. John T. McNeill (1941:211-227) calls these the "passive" elements in Luther's thought. 


\subsection{The purpose of natural law}

Natural law aims at maintaining peace in the temporal sphere of creation. Luther alludes to Abraham's demeanour when he separated from his nephew Lot as exemplary conduct in the furtherance of peace. Abraham, by yielding his right to Lot, strove to maintain peace between them. In similar fashion, the purpose of all earthly laws is peace, harmony and quiet. All rights and all laws, of whatever kind they are, must be directed at maintaining peace, although, of course, human laws are not to be put on a par with the laws of God in every respect (LW, 2:338 ff. (LG); Gen. 13). Luther calls upon Christians, whenever public peace is in danger, to let love be the queen and teacher "who moderates the laws and modifies them with a view toward lessening their severity" (LW, 2:338 ff. (LG); Gen. 13:9, 10). Natural law therefore has an equitable effect, thereby moderating the harsh effects of applying positive law. Luther criticises those "foolish lawyers" and "reprehensible conformists" who do not recognise the use and purpose of laws. Laws, like medicine, must serve to protect, aid and restore health. They have their canons and rules, but these are not to be stressed too rigidly (LW, 2:338 (LG); Gen. 13). Thus in the case of governments the purpose of preserving peace must always be kept in mind. If a prince were to punish the offences of his people in such a way as to give occasion for uprisings, it would be better for him to close his eyes to the offences than to punish them. "What good is the law if it fails in its purpose and if everything goes to pieces?" (LW, 2:339 ff. (LG); Gen. 13). The emperor as the manifestation of the "living, breathing" law (lex viva et animata), therefore, always has to bear in mind that peace should be maintained in the enforcement of law (LW, 2:339 ff. (LG); Gen. 13). Peace and love are, so to speak, the "moderator" and "administrator" of all virtues and laws, as Aristotle pointed out regarding clemency. 31 Aristotle's formulation of the principle of geometric equality fulfils an important function in maintaining peace in public life. Geometric equality, to Luther, is a rule of natural law, as well as Augustine's view that not all people should be treated alike, for not all men are equally strong. One must therefore assign to everyone his place and distribute the burdens according to this (LW, 8:171 ff. (LG); Gen. 48). ${ }^{32}$

31 In his Ethics, Book 5, Chapter 10.

32 See Augustine, Regula ad servus Dei, I, Patrologia, Series Latine, XXXII. 


\section{- Luther equates natural law with love}

Because natural law, as the spiritual law of love, is the manifestation of the moral law in the heart of mankind, it is expressive of the two precepts of the law of love: "love your neighbour as yourself" 33 and "so whatever you wish that men would do to you, do so to them". ${ }^{34}$ Natural law contains the basic rules that people need in order to live together with one another: I ought to treat my neighbour the way that I would like to have him treat me (Matt. 7:12), and I should love my neighbour as myself (Luk. 6:31; LW, 42:68 (An Exposition on the Lord's Prayer for Simple Laymen); WA, 2:120, 6:5, 6:49). ${ }^{35}$ Luther in essence equates natural law with love: "For nature teaches - as does love - that I should do as I would be done by (Luke 6: 31) ... that love and natural law always prevail ... Such a free decision is given, however, by love and by natural law with which all reason is filled" (WA, 11:279; LW, 45:128 (Temporal Authority: To What Extent It Should Be Obeyed)). ${ }^{36}$ This point of departure implies that that which is prohibited by the Ten Commandments will also be contrary to the precepts of the natural law of love. 37

\section{- Manifestations of natural law requirements}

Because the precepts of natural law are based on, flow from and are driven by neighbourly love, there is no fixed category of transgressions of the precepts of natural law. These precepts of natural law are, therefore, to be interpreted widely. Luther cites a number of examples of transgressions of natural law precepts: talking badly of your neighbour (LW, 42:68 (LP)); selling goods with the aim of making as much profit as possible (LW, 45:247 (TU)) 38; stripping another of his possessions no matter how clear a right I

Romans 13:9.

Matthew 7:12.

Also see LW, 45:292 (TU); WA, 18 80; LW, 40:97 (HP); WA, 19:638; LW, 46:111 (SS); WA, 32:494-495; LW, 21:235-236 (SM \& M); Matt. 7:13; WA, 40 II:71; LW, 2756 (LG); Gal. 1).

Also note Luther's remarks in WA, 18:80; LW, 40:97 (HP).

37 When we look at natural law we see how right and universal the commandments are. They require nothing toward God or our neighbour but that which anyone would want to see done, either from a divine or from a human point of view.

38 In Luther's Large Catechism of 1529, he describes, with reference to the seventh Commandment, how every merchant at the marketplace thinks he has a perfect right to set any price he pleases on what is his. 
have, so long as I am unwilling myself to be stripped of mine (LW, 45:247 (TU)). Other manifestations of natural law requirements are those in respect of the return of goods unlawfully acquired, where the debtor is poor the law of love requires that the debtor be acquitted, but if the debtor is not poor, he should restore as much as he can (LW, 45:247 ff. (TU)); in any sale natural law requires that the risk lies with the buyer (LW, 45:303 (TU)) 39; the practice of Zins Kauff, which implies that the making of profit is contrary to natural law (LW, 45:296 (TU)). Other examples cited by Luther include compelling rulers in the political sphere to get what the subjects want by using force and violence (LW, 46:34 (AP)), and forcing people into marriage (LW, 46:305 (OM)).

\section{- Written laws should be subject to love-inspired reason}

Man's ability to know and obey natural law - although these precepts have remained the manifestation of God's will - is supplemented and facilitated by the Holy Spirit; only through God's Spirit can man in his fallen state know God's will and the requirements of the spiritual law of love. When men judge according to love they will easily decide and adjust matters without any law books. When they, however, ignore love and natural law they will never hit upon the solution that pleases God, though they may have "devoured" all the lawbooks and jurists. Instead, the more they depend on them, the further they will be led astray. A good and just decision must not and cannot be pronounced out of books, but must come from a "free mind", as though there were no books. Such a free decision is given, however, by love and by natural law, with which all reason is filled.

Luther then cites the weird example of the Duke Charles of Burgundy: a certain nobleman took an enemy prisoner, and when the wife of the prisoner came to ransom her husband, she was forced by the nobleman to lie with him before he would free her husband. He then did not keep his word, beheaded the husband and sent her the corpse. The nobleman was then summoned to marry the woman, after which Duke Charles beheaded the nobleman, gave the woman possession of the nobleman's property and restored her honour (LW, 45:128 (TO)). 40 Luther states that no

39 This is the principle of caveat emptor.

40 Charles the Bold, Duke of Burgundy in 1467-1477, had actually been involved in such a unique case at Vlissingen in 1469 according to the Dutch historian Pontus Heuter (1535-1602), Rerum Burgundicarum libri sex (1639:393 ff.). In 
pope, no jurist, no lawbook could have given him such a decision - it sprang from untrammelled reason, injected by love, above the law in all the books, "and is so excellent that everyone must approve of it and find the justice of it written in his own heart" (LW, 45:128 ff. (TO)). To Luther written laws should be kept subject to love-inspired reason, from which they originally welled forth as from the spring of justice. We should not make the spring dependent on its rivulets, "or make reason a captive of letters" (LW, 45:128. (TO)).

\section{The implications of Luther's natural law theory}

\section{- Man's unique position in God's creation}

Luther was probably the first thinker of the modern era to approach the issues pertaining to natural law theory from the context of Scripture and not primarily from the perspective of philosophy. Luther's natural law theory is therefore solidly embedded in his theology. The first important outflow of Luther's theory reflects on his view of man in God's creation. Natural law according to Luther's theology can only be appreciated from the perspective of man's unique position, status and function in God's creation. To Luther man is a created being, called by God and awarded a mandate in creation to further justice and to maintain peace in the civil sphere. Thereby Luther avoids those theories degrading man to the status of a mere object, subject to an omnipotent law. Luther's message is clear: man is important to God and man has a mission to further justice and peace in God's creation.

In the sphere of natural law God's Word sheds most illuminating light on all aspects concerning justice, natural rights and the laws made by men. To Luther justice is not possible without consulting God's Word and bowing to its demands. From God's Word Luther distinguishes between God's absolute law and human law. Between these two poles natural law plays an important role in "bridging the gap" between the sinless divine law and man's sinful efforts to

Luther's fourth sermon at Weimar, October 25, 1522, on which this treatise is based, he had referred to the wise ruler simply as a "king" (WA, 10:384). Melanchthon relates this same insident in CR (for Corpus Reformatorum), 20, 531, No. XLII. St. Augustine in Sermon on the Mount, xvi, 50, relates a similar story. In his example the deception involved fornication and a woman who was imprisoned for defrauding an official to the public treasury. This was added to a German edition of the treatise already in 1523 (WA, 11:280-281). Note the remarks at WA, 11:281: "Darumb sollt man geschriebene recht under der vernunfft halten, daraus sie doch geqollen sind als aus dem recht brunnen, und nit den brunn an seyne floslin bynden und die vernunfft mit buchstaben." 
accomplish justice in society. Natural law, to Luther, is an important instrument of facilitation between divine law and human law.

\section{- Natural law is subject to God's sovereign will}

Natural law is subject to God's sovereign will and part and parcel of God's creation. In no way does Luther compromise God's sovereignty in his theology of natural law. God, to Luther, is always the supreme Deity that guides, steers and governs creation according to His divine will. In this context natural law empowers man to know what his duties towards others are. By implication this means that man's natural rights towards his fellow men are divinely protected by the natural law of love, and the knowledge of God's will in guarding man's rights in the fulfilment of man's calling in reality, is revealed to man. The legal system is composed of an intricate multitude of rights and norms in their complex inter-relatedness, and this complex reality of legal rights and interests is guided by the precepts of love.

\section{- Luther warns against positivistic and legalistic perspectives on law}

Luther clearly steers away from those views on law that put their trust in man-made positive law as the only "mechanisms" for ensuring justice. By implication Luther warns against positivistic and legalistic perspectives on law because they are apt to lead to confusion, relativism and historicism. Man, therefore, has to revert to a more fundamental system of law, representative of an "ideal", "good", or "true" law for testing man-made law. Mankind is, therefore, confronted with the existential choice to rely on positive law or to appeal to a more fundamental system of natural moral law. This "deeper", "creational" law, according to God's revelation in His Word, provides such a system of ideal law embedded in God's creational and providential work in reality. This "basic", or "fundamental" or "foundational" law differs from the classic views on natural law of pagan antiquity, because to Luther it was not devised by man, but was given with the coming into being of man, created in the image of God. With the creation of man, according to God's Word, God called creation into existence as a perfect reality. Through the Fall of mankind, natural law and human law were subjected to deformation. However, through the death and resurrection of Christ, man, in principle, is redeemed from sin and through the atonement of Christ, man can be restored to the image of God. Natural law also forms part of the perfect creation of God, is currently subject to the deformation of sin, and partakes in the redemptive work of Christ. 


\section{- Natural law not a static system of rational precepts}

With man's fall into sin, natural law was not extinguished, but continued to exist as a moral law in the hearts of mankind. However, natural law is not a static system of rational precepts, but has a dynamic working through the guidance and dynamics of God's Spirit. Man's knowledge of and obedience to the precepts of natural law are enhanced by and through God's Spirit, working through the Word and through faith. Through the Spirit and through faith, working love in man's heart, man is enabled, in spite of his fall into sin, to know and to promote God's will in society. Furthermore, natural law has both a fixed disposition and a dynamic development and application - it is based on God's will because it finds its origin in God's creational will, yet it is also subject to God's providential working in history. Through the guidance of God's Spirit, natural law has an important escathological role to play in man's work until the return of Christ.

\section{- Natural law and escathological hope}

Natural law also plays a foundational albeit "horrifying" role in the escathological hope of the Christian's involvement in the world. The law (including natural law) lifts the masks from the eyes of those who live in self-righteousness; those who think that through their reason, their own rational insights and self-enlightened abilities can secure their own future and that of mankind in its totality. These people are confronted by the power of the Law, which is "a hammer" that crushes rocks, a fire, a wind, and a great and mighty earthquake that overturns mountains (LW, 26:310 (LGS); Gal. 3:20). "The awesome spectacle and the pomp with which God gave the Law on Mount Sinai," says Luther, "symbolises this use of the Law," because it is a "horrible spectacle of the mountain smoking and burning, the black clouds, the lightning flashing," that signifies the work of the law in the life of Christians. Then only is the way prepared for the Spirit to take control and to transcend those mundane sources of hope invented by mankind: humanism, rationalism, self-righteousness, positivism and legalism:

But in the midst of these terrors of the Law, thunderclaps of sin, tremors of death, and the roarings of the devil, Paul says, the Holy Spirit begins to cry in our heart: 'Abba Father'. And this cry vastly exceeds, and breaks through the powerful and horrible cries of the Law, sin, death, and the devil. It penetrates the clouds and heaven, and it reaches all the way to the ears of God

(LW, 26:381 (LG); Gal. 4:16). 
Only through the power of the Spirit can "new decalogues" be written; only then can the principle of the "old Decalogue" be properly understood, developed and applied to the particular circumstances under which Christians find themselves (see Althaus, 1972:30-35) and can positive law become the variable extension of natural law. Thereby the writing of "new decalogues" means the active development of the Pauline concept of the relative law of love confronting the moral failure of mankind. 41

\section{- In Christ we can make laws}

The function of the law in the life of Christians is succinctly expressed by Klaus Nürmberger (2005:114-115): participating in the authority of Christ as the representative of God, we are no longer under the law; the law is under us. That means that we are responsible for the formulation of the law: "If we had to lose one of the two, Christ or the law, then we would have to lose the law, not Christ. Because if we have Christ, we can easily make new laws and have sound judgment in everything". Indeed, we could make new decalogues, just as Paul does in all his epistles, and Peter, and, most of all, Christ in the Gospel(s). And these decalogues are much clearer than the Decalogue of Moses, "just as the face of Christ is clearer than the face of Moses". Luther adds: "However, because we are not equally in the Spirit, and because the flesh is hostile to the Spirit, and (to counter) the Enthusiasts, it is necessary to stick to certain commandments and the Scriptures of the Apostles, so that the church is not torn apart" (WA, 39 (I): 47ff. (H) 94).42

\section{- Christians should use their powers of observation and reason}

The fact that we can write new decalogues implies that believers, in trying to figure out what the redeeming will of God might be in any new situation, do not only consult Scripture, but use their God-given powers of observation and reason. In doing that they may take into

41 This view confirms the impression that Luther's natural law teachings were fundamental to his ethical and political thinking, and deeply rooted in his theology.

42 Nürnberger (2005:115) observes that this is what Luther in fact did. Using the Ten Commandments as a basic grid, Luther wrote hundreds of pages on specific ethical guidelines and moral precepts. He adds: "It is amazing how perceptive, comprehensive and specific Luther's examples are. Apart from his two Catechisms, his treatise On good works is the most famous example of writing 'new decalogues'. Here he does not discard the biblical decalogue but interpets it in quite a fresh way." 
consideration what the Bible says about a specific issue, but they may also listen to classical Greek or Roman authors. Because we are sons and daughters of God and brothers and sisters of Christ, we partake in his sovereignty. The followers of Calvin would be tied much more closely to what the Bible says about moral patterns of behaviour and what would be more appropriate in the legal sphere (see Nürnberger, 2005:115). Applied to the sphere of natural law, it means that the precepts of natural law cannot remain static; they change with the times and so do the challenges that confront the believer who may be concerned about justice in the civil sphere.

\section{- Working out man's destiny in the civil sphere}

Luther's view of natural law, as the spiritual moral law of love, transcends the age-old conflicts of reason versus will; of rights versus norms; of state versus the individual, and of natural law versus positivism - it becomes the "mediating" instrument in dispensing God's grace and love through the working of God's Spirit in man's sinful existence in the twenty-first century. The essence of Luther's teaching is that without grace, man is not able to work out his destiny in the civil sphere, because natural law theory contains answers to the negative and critical judgments brought about by the secularisation of contemporary life - natural law acts as the "messenger" between the Kingdom of God and the kingdom of creation in order to supercede the secular order, to ennoble it and to convert its hardness into something divine and humane. Furthermore, current secular individualism in law and justice is subjected to Luther's vision of community as the highest reward. Not only does Luther tone down the optimistic secular aims of making civilisation identical with the Kingdom of God, he also inspires Christians to work towards an idealised society as a Christian duty. Meaningful legal reform can only be accomplished by the dynamics of love and it can only endure if it is constantly renewed by the consciousness of the union with God. Natural law is an important medium demanding that the effects of Christian love become manifest in man and the secular order. The most fundamental right is the right to love, because the law of love is the most steadfast and certain of all laws:

You will find no law of greater certainty than the law of love ... You must handle the question of unlawful possession, whether in secret or in public, in such a way that love and natural law remain pre-eminent. For if you pronounce judgement according to love, you will be able to settle and dismiss all legal cases without trouble and without legal textbooks. But if you lose sight of love and natural law you will never succeed in pleasing God 
with your judgement, even should you devour all legal textbooks and all lawyers ... (MA, 5:40).

Different from some of the later Reformers, for example Calvin, Luther did not bind the ideal Christian patterns of behaviour to a more static system of precepts in the form of the Old Testamentary Decalogue - in the legal sphere Christians are expected to consider God's will for them and the whole of mankind in the ever-changing circumstances of history. The fluid demands of justice require believers to make concrete the redeeming will of God in the legal domain by not only consulting the Bible, but by using their Godgiven powers of observation and reason; by practising benevolence in all social relations. The duty of neighbourly love at the heart of Luther's natural law view postulates demands of benevolence of an anti-positivistic and anti-legalistic nature in all social relations. Therefore, there is no room for the unbridled personal powers or will of political rulers, or for the humanistic efforts to make law without reference to values at a deeper level of human existence, or for secular efforts to idealise man's natural reason or powers of will.

\section{- Perspectives on rights and duties}

Luther's natural law theory also introduced important new perspectives on responsibility in the world - a Christian lives under the duty to act even without the compulsion of law; it demands of him, as Holl (1959:30) says, to produce from his individual sense of the divine will "by his own creative act the proper form of morality in a specific instance". The individual's duty to promote God's demands of love is supported by the right to promote justice, which right flows from the individual's freedom of conscience - something that is inviolable. Man's duty and right to promote love in the kingdom of creation is a "vital, creative, active thing, which works unceasingly and is ever busy", the true Christian is not idle; or if he is, his conscience bothers him (Holl, 1959:32). In the final instance, concretising and promoting the spiritual law of love does not only serve the neighbour, it also produces complete joy in the life of the believer.

Although Luther was, arguably, perhaps too optimistic concerning the work of the Spirit in the present world, and the role of natural law in furthering love and peace among men, there can be no doubt as to his strong opposition to putting man's trust in governments or legislation as mechanisms for furthering justice in society. His call to believers that they can and should make a meaningful difference in legal systems across the world carries a relevant message even in the 21 st century. 


\section{List of references}

ALTHAUS, P. 1972. The ethics of Martin Luther. (Transl. by Robert C. Schultz). Philadelphia: Fortress.

AUGUSTINE. 1997. Anti-Pelagian Writings. (In Schaff, P. ed. Ages digital library. The Nicene and post-Nicene Fathers. First Series. Vol. 5. Transl. by Peter Holmes, P. \& Wallis, R.E. Albany, or, Books for the Ages.)

AUGUSTINE. 1997. Enchiridion. (In Schaff, P., ed. Ages digital library: the Nicene and post-Nicene Fathers. First Series. Vol. 3. Transl. by Shaw, J.F. Albany, or, Books for the Ages.)

AUGUSTINE. 1997. On Christian doctrine. (In Schaff, P., ed. Ages digital library: the Nicene and post-Nicene Fathers. First Series. Vol. 2. Transl. by Shaw, J.F. Albany, or, Books for the Ages.)

AUGUSTINE. 1997. Treatise on Spirit and the letter. (In Schaff, P., ed. Ages digital library. The Nicene and post-Nicene Fathers. First Series. Vol. 5. Transl. by Holmes, P. \& Wallis, R.E. Albany, or, Books for the Ages. )

BEYER, H.W. 1935. Luther und das Recht: Gottes Gebot, Naturrecht, Volksgesetz in Luthers Deutung. Munich: Chr. Kaiser.

BINDER, J. 1965. Hermeneutik der Rechtslehre Martin Luthers. Archiv für Rechts- und Sozialphilosophie, 51:337 ff.

BORNKAMM, H. 1969. Luther and the Old Testament. (Trans. by Gritsch, E.W. \& Gritsch, R.C.) Philadelphia: Fortress.

BROWN, H.O. 1987. Martin Luther: a natural law theorist? (In Johnson, H.J., ed. The Medieval tradition of natural law. Studies in Medieval Culture, XXII. Kalamazoo: Western Michigan University. p. 13-25.)

CARGILL THOMPSON, W.D.J. 1984. The political thought of Martin Luther. Brighton: The Harvester Press.

DOWEY, E.A. 1984. Law in Luther and Calvin. Theology Today, 41(2):146-153, Jul.

EBELING, G. 1963. Word and faith. (Transl. by Leitsch, J.) Philadelphia: Fortress.

HECKEL, J. 1953. Lex charitatis: eine juristische Untersuchung über das Recht in der Theologie Martin Luthers. Munich: Verlag der Bayerischen Akademie der Wissenschaften.

HEUTER, P. 1639. Rerum Burgundicarum libri sex. Hague: Comitis.

HOLL, K. 1932. Gesammelte Aufsätze zur Kirchengeschichte. 3 Vols. Tübingen: Mohr.

HOLL, K. 1959. The cultural significance of the Reformation. (Transl. by Lichtblau, J.H.) New York: Meridian Books.

LAU, L. 1933. "Ausserliche Ordnung" und "weltliche Ding" in Luthers Theologie des Politischen. Göttingen: Vandenhoeck \& Ruprecht.

LUTHER, M. 1883-1987. Werke: kritische Gesamtausgabe (WA) (78 Vols.). Weimar: Hermann Böhlaus Nachfolger.

LUTHER, M. 1958-1967. Works (LW) (55 vols.). Eds. Pelikan, J. (Vols. 1-30) \& Lehmann, H. (Vols. 31-55). Philadelphia: Concordia.

LUTHER, M. 1963-2005. Ausgewählte Werke (MA). Reds. Borcherdt, H.H. \& Merz, G. München: Kaiser. (Vols. 1-6 \& supplementary volumes 1-7.)

MELANCHTHON. 1944. The Loci communes. (Transl. by Hill, C.H.) Boston: Meader.

McNEILL, J.T. 1941. Natural law in the thought of Luther. Church History, 10:211-227. 
NICHOLS, S.J. 2002. Martin Luther: a guided tour of his life and thought. Phillipsburg: P \& R Publishing.

NÜRNBERGER, K. 2005 Martin Luther's message for us today. Pietermaritzburg: Cluster Publications.

SCHLOEMANN, M. 1961. Natürliches und gepredigtes Gesetz bei Luther. Berlin: Töpelmann.

SIIRALA, A. 1956. Gottes Gebot bei Martin Luther. Helsinki: Schriften der Luther-Agricola-Gesellschaft.

TONKIN, J. 1971. The church and the secular order in reformation thought. New York: Columbia University Press.

TROELTSCH, E. 1960. The social teachings of the Christian churches. (Transl. by Wyon, O.) New York: Harper Torchbook.

WOLF, E. 1954. Naturliches Gesetz und Gesetz Christi bei Luther. (In Peregrinatio. Studien zur reformatorischen Theologie und zum Kirchenproblem. Munich: Chr. Kaiser. p. $191 \mathrm{ff}$.)

WÜNSCH, G. 1936. Evangelische Ethik des Politischen. Tübingen: Mohr/Siebeck.

\section{Key concepts:}

Martin Luther

natural law

positive law

St. Augustine

St. Paul

Kernbegrippe:

Augustinus

Martin Luther

natuurreg

Paulus

positiewe reg 